\title{
Exchanging knowledge in the TMT to realize more innovation opportunities: what can family firms do?
}

\section{Emanuela Rondi and Paola Rovelli}

Emanuela Rondi is based at the Department of Management, Università degli Studi di Bergamo, Bergamo, Italy. Paola Rovelli is based at the Centre for Family Business Management of the Faculty of Economics and Management, Libera Università di Bolzano, Bolzano, Italy.
Received 28 August 2020 Revised 21 December 2020 16 March 2021

Accepted 23 April 2021

(C) Emanuela Rondi and Paola Rovelli. Published by Emerald Publishing Limited. This article is published under the Creative Commons Attribution (CC BY 4.0) licence. Anyone may reproduce, distribute, translate and create derivative works of this article (for both commercial and non-commercial purposes), subject to full attribution to the original publication and authors. The full terms of this licence maybe seen at http://creativecommons.org/licences/by/4.0/ legalcode

This work was financially supported by the Chamber of Commerce of Bozen-Bolzano.

\begin{abstract}
Purpose - This paper aims to examine the influence that family firms' top management team (TMT) behavior and characteristics exert on their innovation opportunity realization.

Design/methodology/approach - Data were collected through a survey addressed to a representative sample of Italian firms. The analyzed sample consists of 237 firms, 120 of which are family firms. A series of ordinary least squares models were used to test the four hypotheses.

Findings - Family firms realize fewer innovation opportunities than non-family firms. This result is fully mediated by the knowledge exchange in the TMT as follows: in family firms, the TMT exchanges less knowledge than in non-family firms, which drives their lower realization of innovation opportunities. In family firms TMT, the increase in the non-family members positively influences the TMT knowledge exchange, but only when the time the Chief Executive Officer (CEO) spends in searching for innovation opportunities outside the firm is low. The more the CEO search increases, the more this positive influence decreases, up to the point it becomes negative.

Research limitations/implications - The study contributes to the literature on innovation, knowledge management and organizational design in family firms. Nevertheless, data were collected at a single point in time and in a single country.

Practical implications - The study suggests family firms on how to foster the realization of innovation opportunities. A greater TMT knowledge exchange allows to realize more innovation opportunities and the TMT characteristics emerged as the drivers of this TMT knowledge exchange. As such, family firms should examine the interaction of their TMT composition in terms of non-family and family members with the effort that the CEO deploys to search for innovation opportunities outside the firm.

Originality/value - Empirical investigation of the link between family ownership, absorptive capacity and innovation performance by considering TMT behavior and characteristics.

Keywords Family firms, Innovation management, Opportunity realization, Top management team, Knowledge exchange, Absorptive capacity, Organizational design, TMT characteristics,

TMT composition, CEO behavior, CEO search

Paper type Research paper

\section{Introduction}

Knowledge - the relevant and actionable information based on experience and education (Cabrera-Suárez et al., 2001) - allows organizations to be innovative (Nonaka and Takeuchi, 1995). Family firms have been identified as distinctive for the temporal search of past knowledge that through interiorization and reinterpretation capabilities can be leveraged to innovate (De Massis et al., 2016). Yet, it is also important for them to acquire and develop new knowledge in the present to innovate. In this regard, scholars interested in family firm innovation have examined the accumulation and recombination of knowledge (Chirico and Salvato, 2008), knowledge internalization in new product development (Chirico and Salvato, 2016) and absorptive capacity (Brinkerink, 2018; Kotlar et al., 2020) - i.e. "a set of
\end{abstract}


organizational routines and processes by which firms acquire, assimilate, transform and exploit knowledge" (Zahra and George, 2002). However, little is still known about family firm's knowledge management for innovation purposes (Döring and Witt, 2020).

More recently, studies have started examining elements of heterogeneity among family firms in regard to innovation (Calabrò et al., 2019), yet leaving the mechanisms of knowledge management under investigation (Brinkerink et al., 2020; Del Giudice et al., 2010; Chirico, 2008). Research on family firm innovation has investigated the presence of family members in the business ownership and/or management, in terms of organizational structure, as the driver of a firm's innovation performance (De Massis et al., 2013). Under this line of inquiry, knowledge management research has also identified organizational design - i.e. the structure of an organization adopted to realize its goals and perform certain activities (Nadler and Tushman, 1997; Russo and Harrison, 2005) - as one of the most influential elements (Claver-Cortés et al., 2007). Recently, scholars examining family firms have identified the organizational design of the top management team (TMT), which is responsible of the firm's strategic decision-making (Collins and Clark, 2003; Amason, 1996), as the main driver of family firms' opportunity realization (De Massis et al., 2020).

However, research has only recently started scratching the surface about the role played by the TMT behavior and characteristics in innovation (Kammerlander et al., 2020; Kraiczy et al., 2014; Woodfield and Husted, 2017; Röd, 2019) and little is known about the underlying mechanisms of knowledge management that influence firm's innovation performance. Specifically, we argue that to realize an innovation opportunity - i.e. actual deployment of actions, resources and investments in the pursuit of perceived innovation opportunities (Foss et al., 2015) - it is important to consider organizational absorptive capacity (Cohen and Levinthal, 1990). Therefore, in this study, we address the following research question: What influence does the TMT exert on knowledge management in pursuing innovation opportunity realization? In so doing, we focus on TMT behavior and characteristics, intended as TMT knowledge exchange, TMT composition (family vs nonfamily members) and the effort deployed by the Chief Executive Officer (CEO) in searching for innovation opportunities outside the firm [1] (hereafter: CEO search).

To pursue our aim, we analyzed a sample of 237 Italian firms, 120 of which are family firms. We gathered information of firms' innovation opportunity realization and TMT behavior and characteristics through a survey data collection; then, we complemented these data with information on general firm characteristics retrieved from secondary sources. Ordinary least squares (OLS) models revealed that family firms do realize fewer innovation opportunities than non-family counterparts. This result is explained by the lower TMT knowledge exchange that characterizes family firms and that fully mediates the relationship between the family nature of the firm and the realization of innovation opportunities. To the final aim of realizing more innovation opportunities, family firms can foster TMT knowledge exchange by increasing the number of non-family members in their TMT. Nevertheless, the influence that the increase in non-family TMT members has on TMT knowledge exchange is positive only when the CEO spends limited time in searching for innovation opportunities outside the firm. When the CEO search increases, this positive influence decreases, up to the point it becomes negative.

Building on our findings we contribute to the literature on innovation, knowledge management and organizational design in family firms. We extend the knowledge-based perspective on family firm innovation (Chirico and Salvato, 2016; Cabrera-Suárez et al., 2018) by demonstrating differences in the level of knowledge exchange in family and nonfamily firms' TMT and identifying TMT knowledge exchange as the mechanism that explains family firms' lower realization of innovation opportunities. In so doing, we contribute to the current understanding of the relationship between family ownership and innovation performance by shedding light on the family firm's absorptive capacity (Kotlar et al., 2020), which mediates the organizational ability to develop innovation outputs. Moreover, we 
extend the current understanding of family firm heterogeneity by exploring alternative configurations of organizational design elements (Kraiczy et al., 2014; Röd, 2019). Our findings show that TMT composition and CEO search in concert rather than in isolation are determinants of TMT knowledge exchange and, in turn, of innovation opportunity realization (Cao et al., 2010). In so doing, we combine internal and external perspectives by, respectively, considering the level of TMT knowledge exchange and the network of external contacts of the TMT members and CEO search behavior (Zahra et al., 2007; Kammerlander et al., 2020). Such endeavor allowed us to grasp the mechanisms of absorptive capacity through which family firms acquire external novel knowledge (examining the role of external networks of contacts), assimilate and transform it within the TMT and exploit it to realize innovation opportunities. Our study consists in one of the first attempts to examine TMT characteristics and behavior by grasping the interaction of organizational design and searching activities (Mazzelli et al., 2019) in driving a family firm's innovation outcomes.

\section{Hypothesis development}

\section{Family vs non-family firms and innovation opportunity realization: the mediating role of top management team knowledge exchange}

The shortened life cycle of products in highly competitive markets has enforced the crucial role of innovation as powerful strategic means to acquire, nurture and maintain organizational competitive advantage (Cardinal, 2001). Research has been interested in examining the innovation behavior of organizations (Ahuja et al., 2008) in relation to innovation inputs - i.e. firm's financial investments dedicated toward the exploration and exploitation of new opportunities (Duran et al., 2016) - and innovation outputs - i.e. realized opportunities - as well as the innovation process that transforms inputs into outputs (Garud et al., 2013). To transform innovation inputs into outputs, firms need to appropriately manage acquired and developed knowledge to produce value (Sirmon et al., 2011); in fact, even when investing a high amount of innovation inputs, organizations might end up with low or none outputs if knowledge is badly managed.

Among the different innovation outputs, the realization of innovation opportunities (Foss et al., 2015) has recently been found to be shaped by the influence exerted by the family on the business (De Massis et al., 2020). As such, the success of family firms depends not only on their identification of innovation opportunities in the environment but also particularly on their realization of such opportunities (Barney et al., 2018; Rovelli et al., 2020). In this regard, family firms seem to be less prone to realize innovation opportunities to prevent the jeopardization of the family wealth, thus causing them to invest less in entrepreneurial endeavors than non-family firms (Goel and Jones, 2016). Therefore, the family nature of the firm is likely to negatively influence the realization of innovation opportunities. Thus, in our baseline hypothesis, we argue that as follows:

H1. Family firms realize fewer innovation opportunities than non-family firms.

Given the importance of innovation for firms' success and survival, it is necessary to dig deeper into the factors that explain the alleged negative discrepancy in innovation opportunities realization between family and non-family firms. Nowadays, industry winners are organizations able to realize innovation opportunities arising from knowledge-based assets (Goh, 2005; Grant, 1996). A vast body of research has shown an influence of absorptive capacity in enacting innovation opportunities (Kostopoulos et al., 2011; Cohen and Levinthal, 1990; Zahra and George, 2002). According to Darroch (2005), knowledge plays a threefold role as being a resource for innovation, supporting decision-making about resource orchestration in innovation management and directly contributing to the development of innovation, so that "a firm capable in knowledge acquisition, knowledge dissemination and responsiveness to knowledge is more innovative" (Darroch, 2005). As "knowledge is strategically valuable only when is shared, synthesized and used in unique 
ways" (Zahra et al., 2007, p. 1070), firms need to be able to integrate knowledge generated internally through activities of research and development (R\&D) with externally acquired knowledge to expedite innovation opportunity realization (Foss et al., 2013). Therefore, examining the factors that favor the flow and use of knowledge is of key importance to the final aim of further realizing innovation opportunities.

Sharing knowledge within organizations is crucial (Lenox and King, 2004), especially in complex processes of innovation that require feedback loops among organizational functions and departments (Baldwin and Clark, 2000). Knowledge sharing allows to assimilate, transform and exploit developed or acquired knowledge, especially within the TMT, which is responsible for making strategic decisions (Amason, 1996; Collins and Clark, 2003) about the innovation opportunities to realize and the actions to put in place (Foss et al., 2015; Ling and Kellermanns, 2010). As such, the exchange of knowledge among TMT members drives the realization of identified innovation opportunities (Damanpour, 1991) so that a high level of knowledge exchange within the TMT facilitates the realization of innovation opportunities (Simsek et al., 2005).

Prior research has highlighted the influence that the TMT exerts on organizational performance, particularly in family firms (D'Allura, 2019). Family firms are characterized by unique governance practices such as the centralized authority in the hands of the CEO (Carney, 2005; Feltham et al., 2005) and the desire for strong control over decision-making that can limit the TMT participation (Gómez-Mejía et al., 2007; Kammerlander and Ganter, 2015) in these decision-making processes. Promoting knowledge exchange among TMT members can be cumbersome for family firms, as knowledge often resides in individuals or a restricted number of family members and represents a source of power asymmetry (Zahra et al., 2007). In addition, family rivalries may reduce the willingness of senior generations to exchange knowledge with junior generations (Woodfield and Husted, 2017) and the same may hold across family branches in the TMT. Moreover, family influence can make knowledge practices more complex in family firms, as in presence of nepotism that can undermine the integration of novel and divergent knowledge (Zahra et al., 2007). Therefore, members of family firms' TMT are less likely to exchange knowledge either internally developed or externally acquired, leading to inertia (Woodfield and Husted, 2017). We hypothesize that such attitude drives lower organizational absorptive capacity (Kotlar et al., 2020) - specifically in knowledge assimilation, transformation and exploitation - in turn, limiting family firms' realization of innovation opportunities. We, thus derive the following hypothesis, which is represented in Figure 1 below:

H2. TMT knowledge exchange mediates the alleged negative relationship between family firms and realized innovation opportunities.

Figure 1 Conceptual framework (1)

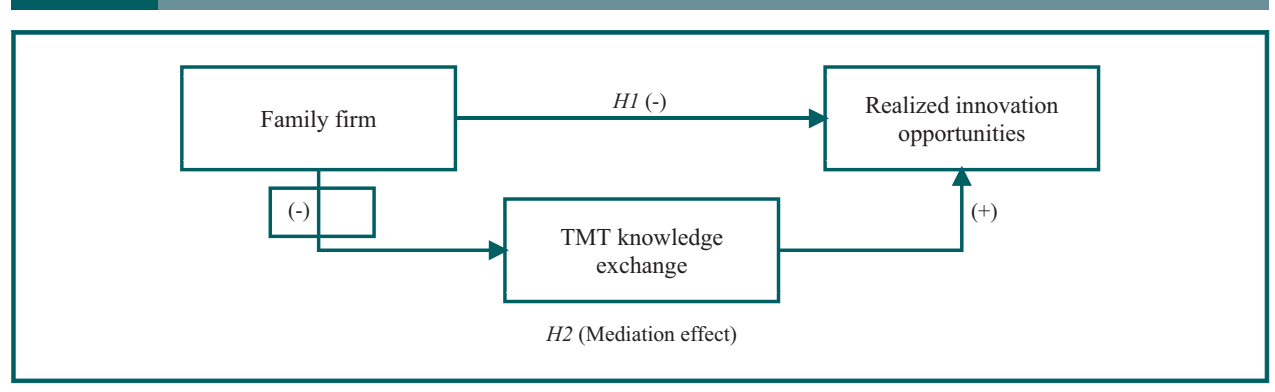

VOL. 26 NO.2 2022 JOURNAL OF KNOWLEDGE MANAGEMENT $\mid$ PAGE 353 


\section{Fostering top management team knowledge exchange within family firms}

In the light of the hypothesized lower TMT knowledge exchange in family firms - which consequently leads to fewer realized innovation opportunities - we argue that it is paramount to delve into factors that might spur knowledge exchange within the family firm's TMT (Patel and Cooper, 2014). Novel information boosts knowledge exchange, especially when organizational actors acquire ideas from outside that require to be shared within the TMT to be assimilated with internal knowledge and transformed into the specific innovation needs of the firm to be realized. Firms need to search broadly for diverse and complementary sources of external knowledge (Fleming and Sorenson, 2001) so that once the external knowledge is available within them, they can assimilate and transform it in their self-domain (Ciarrochi and Forgas, 2000). Coherently, innovation literature has vastly recognized the crucial role of external networks as allowing access to knowledge and resources unavailable through market exchanges (Rothaermel and Hess, 2007).

The broad social structure of the TMT spans the boundaries of the organization, allowing its members to socialize with actors from diverse sets of groups, developing bridging relationships (Oh et al., 2004). Each member of the TMT might rely on a specific network whose variety brings different pieces of knowledge that can be combined for innovation purposes (Kammerlander et al., 2020). Therefore, TMT members connected to a broad range of non-redundant actors beyond the firm boundaries tend to access more novel, timely and diverse knowledge (Oh et al., 2006). Once accessed, the knowledge acquired from the external network of contacts needs to be assimilated and contextualized to the business' needs and domains. Therefore, when TMT members have a wider range of bridging relationships, they are more likely to adopt a high level of exchange. Conversely, when TMT members' external networks of contacts are highly in overlap, the knowledge acquired is redundant and the resultant dense network restricts the formation of relationships that allow to access more varied innovative knowledge (Hansen et al., 2005; Portes and Sensenbrenner, 1993). In this latter case, the high overlap of the TMT external social network leads to redundant and homogeneous knowledge that undermines its exchange in the TMT.

Coherently with recent studies that are exploring family firm heterogeneity in relation to TMT composition (Röd, 2019), we argue that the presence of non-family members in the TMT is indicative of the degree of network sparseness, a means to access external novel and nonredundant knowledge (Yli-Renko et al., 2001). Research has shown that diversity increases creativity and TMT consisting only in family members misses the external perspective provided by non-family members (Kammerlander et al., 2020). Building on this view, when the TMT is composed of sole family members, it is likely to encounter issues related to a closed and dense social network (Alguezaui and Filieri, 2010) leading to redundant knowledge, thereby limiting the flow of TMT knowledge exchange. Including more nonfamily members in the TMT increases the potential for boundary-spanning, as the external network of contacts is sparser and more heterogeneous, thereby accessing novel and nonredundant knowledge that needs to be exchanged in the TMT to be assimilated and transformed into the family firm's domain. Thus, we hypothesize as follows:

H3. In family firms, the increase in the ratio of non-family members in the TMT positively influences the TMT knowledge exchange.

Although the interaction with external knowledge sources is proven to expedite opportunity realization, communication with external parties may not occur spontaneously, thereby requiring active search - i.e. firm's proactive efforts at accessing knowledge relevant to its own purposes (Katila and Ahuja, 2002; Katila, 2002). To acquire external knowledge, TMT members need to scan the environment to identify complementary sources (Zahra and George, 2002). Therefore, TMT members in family firms need to extend their search scope by purposefully exploring external sources of knowledge (Katila and Ahuja, 2002). 
However, the CEO is not the same as any other TMT member (Cao et al., 2010) and in family firms, her/his approach to search (Mazzelli et al., 2019) is particularly influential for the future trajectories and decisions made by the TMT (Kammerlander et al., 2020). In fact, the highly centralized authority that characterizes family firms (De Massis et al., 2020) likely leads the CEO to be the one taking the responsibility for the search activities of the business (Mazzelli et al., 2019). When a CEO deliberately dedicates to external search, he/she is more likely to rely on the knowledge directly accessed rather than consulting the TMT to make decisions about innovation opportunities to realize. Consequently, building on the joint effect of TMT and CEO behavior in innovation (Cao et al., 2010), we contend that the above hypothesis is contingent on the effort that the family firm's CEO devotes to active search. The influence of the TMT composition on the TMT knowledge exchange decreases in importance when the CEO engages more in active search, thus having a lower need to rely on the external network of non-family TMT members to acquire novel knowledge. Therefore, we hypothesize that the CEO's external search for innovation opportunities negatively moderates the positive influence of non-family TMT members on the knowledge exchange with the team. Thus, we hypothesize as follows:

H4. In family firms, the increase in the CEO's external search for innovation opportunities negatively moderates the alleged positive relationship between the ratio of nonfamily members in the TMT and TMT knowledge exchange.

In Figure 2 below we synthesize $\mathrm{H} 3$ and $H 4$.

\section{Method}

\section{Data collection and sample}

To study the role played by knowledge exchange in the TMT in the realization of innovation opportunities by family firms and whether and how TMT composition and CEO search affect TMT knowledge exchange, we resorted to a database developed through a survey data collection. The database includes information on Italian firms and their CEOs and TMTs that are not publicly available on secondary sources. The latter were instead used to gather data to control for possible confounding factors.

The survey data collection was addressed to the CEOs of a sample randomly extracted from the target population of 50,341 Italian firms with at least 20 employees and operating in the manufacturing and services industries. The sample was stratified along with the three dimensions of size (20-49, 50-249, 250-499 and 500 or more employees), industry (manufacturing and services) and geographical location (North, Center and South of Italy) and included 6,108 firms. Nevertheless, it was possible to find CEOs' contact information for a sub-sample of 3,899 firms. To these CEOs, a structured questionnaire was administered by email. The purpose of the questionnaire was to study the organization of Italian firms' TMTs. In our case, we took advantage of the questions designed for collecting information on the innovation opportunities realized by the firm, the knowledge exchange in the TMT and the composition of the TMT and the search for innovation opportunities of the CEO. To

\section{Figure 2 Conceptual framework (2)}

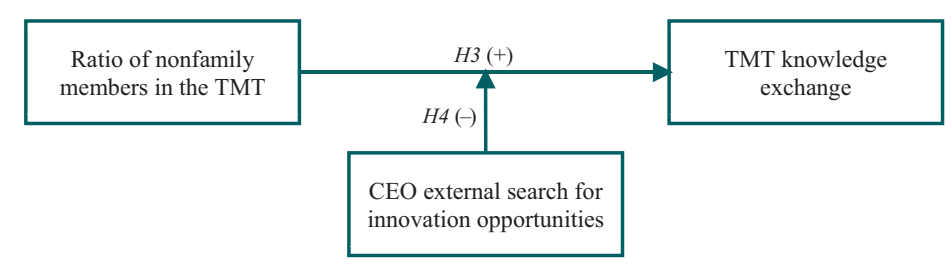


develop the questionnaire, questions and constructs already validated in previous research were used. Following established practices, these questions were first translated into Italian and then back-translated into English to guarantee the preservation of their original meaning (Dillman, 2000; Kriauciunas et al., 2011). The questionnaire was also pilot tested and pre-tested (Andrews et al., 2003; Collins, 2003; Kriauciunas et al., 2011).

363 CEOs replied to our questionnaire. The response rate of $9.31 \%$ is consistent with that of other survey data collections conducted in similar studies (Garcés-Galdeano et al., 2017; Poterba and Summers, 1995; van Doorn et al., 2017; Graham et al., 2013; Simsek, 2007; Cruz et al., 2010). However, only 241 questionnaires presented complete information on our main dependent variables (i.e. the realization of innovation opportunities and the knowledge exchange in the TMT). To test the quality of the data, we made several checks that confirmed the representativeness of the sample with respect to the population, the absence of non-response biases and the reliability of CEOs' answers. More information on these tests is provided in the Appendix while Rovelli (2017) and Rovelli and Rossi-Lamastra (2018) offer a thorough description of the survey data collection.

To complement survey data with information on general firm characteristics, we used secondary sources [i.e. the Analisi Informatizzata Delle Aziende Italiane (AIDA) database]. Due to missing data, the sample we used to test $\mathrm{H} 1$ and $\mathrm{H} 2$ consists of 237 Italian firms. In total, 120 of these (50.6\%) are family firms, which we considered to test $\mathrm{H} 3$ and $\mathrm{H} 4$.

\section{Measures}

The main variables we used to test the hypotheses concern as follows: the family nature of the firm (Family firm), the firm's realization of innovation opportunities (Realized innovation opportunities), the exchange of knowledge in the TMT (TMT knowledge exchange), the family and non-family composition of the TMT (TMT composition) and the extent to which the CEO looks for innovation opportunities outside the firm (CEO search).

A family firm is a dummy variable equal to one in the case of this type of firm. We identified family firms considering both self-identification and ownership. First, we used the selfidentification criterion (Harveston et al., 1997; Mahto et al., 2010; Cruz et al., 2010) asking directly to CEOs about the nature of their firm. Second, we checked CEOs' answers with the ownership data provided by AIDA. In line with previous studies, we identified as family firms those where members of the same family control more than $50 \%$ of the shares (Minichilli et al., 2010). The two criteria led to the same sample of family firms. This means that, in line with previous literature (Miller et al., 2013; Harveston et al., 1997; Mahto et al., 2010; Ling and Kellermanns, 2010), we identified family firms through both the involvement and essence criteria (Chrisman et al., 2012).

To measure the firm's realization of innovation opportunities we used the data gathered through the survey data collection. Taking inspiration from Foss et al. (2013, 2015), CEOs were asked to assess the amount of opportunities successfully realized by their firm in the past three-years, using a seven-point Likert-type scale ranging from "no opportunities" (1) to "many opportunities" (7). Seven types of opportunities were provided as follows: new products and services; new production technologies; entry into new markets; changes in the organization; new ways to manage the human resources; new ways to manage the R\&D and new ways to manage the accounting and finance. Following previous studies (Foss et al., 2013; Rovelli et al., 2020), we selected four items as related to innovation: new products and services, new technologies, new markets and new ways of managing R\&D. The higher are the averages of these four items, the higher is the number of innovation opportunities realized. We validated this classification by means of a Confirmatory Factor Analysis and we used the corresponding factor as a measure of Realized innovation opportunities. 
Regarding the TMT, to assess the exchange of knowledge among its members we used as a proxy the measure of information exchange proposed and validated by Simsek et al. (2005) and then used in subsequent studies (Ling and Kellermanns, 2010). This variable was measured by asking CEOs to think about situations over the past two years when the TMT made important decisions regarding the future of the firm (e.g. those concerning the realization of innovation opportunities) and evaluate, using a five-point Likert-like scale ranging from "low" (1) to "high" (5), their team's as follows: quantity of the exchanged ideas, quality of the proposed solutions and level of creativity and innovation of the proposed solutions. We computed TMT knowledge exchange as the factor resulting from a Principal Component Analysis of these items (Cronbach's alpha $=0.757$ ). We measured TMT composition as the ratio of the number of non-family TMT members over the size of the TMT [2].

Our last main variable measures the external search for innovation opportunities by the CEO. Specifically, we used as a proxy of CEO search the working time dedicated by the CEO to search for innovation opportunities outside the firm every week. To create this variable, we took advantage of two questionnaire items dealing with CEO time management (Bandiera et al., 2011; Rovelli, 2020). In the first question, CEOs were asked to consider their typical working week and indicate, among others, the percentage of their working time spent with individuals outside the firm (e.g. customers, suppliers, consultants). In the second question, the CEO had to indicate how frequently (from 1, "very rarely," to 7 , "always") the time spent with external individuals is dedicated, among other things to exploring innovation opportunities. We computed CEO search as the product of these two items, then transformed it into a logarithm due to its skewness.

In our estimate, we added to these five main variables a series of control variables at the firm and CEO levels. As for the former, we included the size of the firm, measured both as the logarithm of the firm's sales (Firm size) and as the number of hierarchical levels between the CEO and the lowest level with budget or expenses responsibility (Firm hierarchical leve/s), the logarithm of Firm age and Firm growth as the average growth in sales in the past three years. We also included some dummy variables to control for whether the firm is a Subsidiary firm, whether it is Controlled by a foreign firm, the Industry in which it operates (equal to one in case of manufacturing) and where the firm is located; in this case, we added two Geographical area dummies representing whether the firm is in the North or South of Italy (the center is the residual category). Finally, we controlled for the TMT size, measured as the number of top executives in the TMT and for Market competition and Market evolution, which inform on the environment in which the firm operates (De Massis et al., 2020). In the questionnaire, CEOs were asked to evaluate with a five-point Likert-type scale whether the market size is rapidly shrinking (1) or rapidly growing (5); the technological change is very slow (1) or very rapid (5); the market has few (1) or many (5) competitors, and industry competitive intensity is very low (1) or very high (5). The following two distinct factors emerged from a Principal Component Analysis: the first (Market evolution) including the first two items, the second (Market competition) including the last two.

At the CEO level, we controlled for Female CEO, a dummy equal to one if the CEO is a woman, CEO MBA, a dummy equal to one in case he/she holds an MBA, CEO tenure, measured as the number of years since he/she was appointed CEO in the current firm and CEO decision power, which measures the number of strategic decisions on which the CEO has decision authority, being delegated by the Board to the CEO.

Finally, when testing $\mathrm{H} 3$ and $\mathrm{H} 4$, we included three additional control variables, which relate to the focus of these hypotheses on family firms and the TMT. First, we added the dummy variable Family CEO, which is equal to one in case the CEO is a member of the family owning the firm. Second, we considered the organizational configuration of the TMT and the level of trust among its members. CEO centric TMT is a dummy variable equal to one in 
case the CEO adopted a CEO-centric TMT organizational configuration to structure its TMT. Following previous literature (De Massis et al., 2020; Rovelli et al., 2020), we derived this configuration from the interplay between six key elements of organizational design (i.e. delegation, incentives, coordination, communication formalization, size), running a two-step cluster analysis applied to these elements. TMT trust indicates instead the level of trust among its members. We measured this variable by adapting the construct proposed and validated by Simons and Peterson (2000). CEOs were asked to evaluate how frequently, over a seven-point Likert-like scale ranging from "very rarely" (1) to "always" (7), the TMT members expect transparency from other members, demonstrate moral integrity, have confidence in the skills of the other members, rely on other members to meet their commitments and know they can trust each other. We computed TMT trust as the factor resulting from a Principal Component Analysis of these items (Cronbach's alpha $=0.859$ ).

\section{Method of analysis}

To test the hypotheses, we ran a series of OLS models, which, depending on the specific hypothesis addressed, rely on different samples and independent variables. Specifically, to test $\mathrm{H} 1$ and $\mathrm{H} 2$ and thus to investigate the relation between the family nature of the firm and the realization of innovation opportunities $(H 1)$ and the mediating effect of the exchange of knowledge in the TMT (H2), we considered the whole sample of 237 firm (i.e. family and non-family) and Family firm as the independent variable. In so doing, we adopted the traditional four-step approach by Baron and Kenny (1986) and the more modern approaches (Hicks and Tingley, 2011; Emsley and Liu, 2013). Therefore, we tested six models. Model 1 includes only control variables. In Model 2 we regress the dependent variable Realized innovation opportunities against the treatment (Family firm). In Model 3 we estimate the moderator (TMT knowledge exchange) given the treatment. In the two following models, the dependent variable is regressed against the mediator (Model 4) and then the mediator and the treatment (Model 5). Model 6 serves instead to support the result of the mediation, testing a moderating effect. Moreover, adopting more modern approaches, we followed Hicks and Tingley (2011) and Sobel (1982) in computing the average causal mediation effect, testing the significance of direct, indirect and total effect and performing sensitivity analyzes; finally, we also used the most recent approach by Emsley and Liu (2013).

To test $\mathrm{H} 3$ and $\mathrm{H} 4$ we used the other four OLS models, which rely on the sample of 120 family firms only and consider TMT composition as the independent variable. These models allowed us to study the relation between TMT composition and TMT knowledge exchange, which is the dependent variable, $(H 3)$ and the moderating effect of $C E O$ search $(H 4)$. Model 7 is the baseline with only control variables. In Model 8 we test the direct effect of TMT composition while in Model 9 we consider also the direct effect of the moderator. Finally, Model 10 tests the moderating effect of CEO search over the direct relation between TMT composition and TMT knowledge exchange. To interpret the results of the moderation, we computed the Average Marginal Effects.

\section{Results}

Table 1 presents the descriptive statistics and correlations. As for the main variables of the study, the Realization of innovation opportunities is not significantly correlated with Family firms and TMT composition. It appears instead positively and significantly correlated with both TMT knowledge exchange (rho $=0.215, p<0.01$ ) and CEO search ( $r$ ho $=0.157, p<$ 0.05 ). The former is positively and significantly correlated with Family firms ( $r h o=-0.126$, $p<0.10$ ). A $t$-test indeed revealed a significant difference in the TMT knowledge exchange of family and non-family firms $(p<0.10)$. 


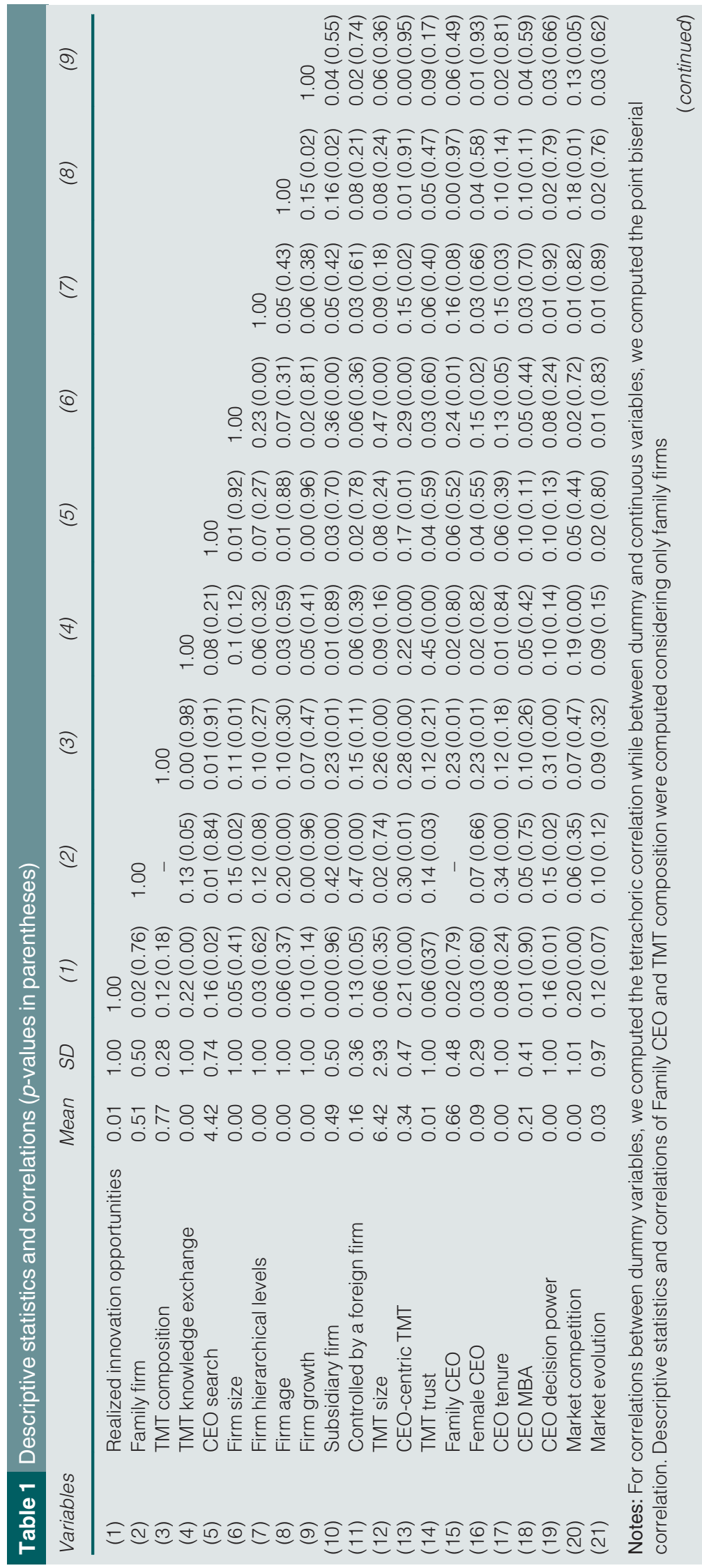

\begin{tabular}{l|l|l} 
VOL. 26 NO.2 2022 & JOURNAL OF KNOWLEDGE MANAGEMENT & PAGE 359
\end{tabular} 


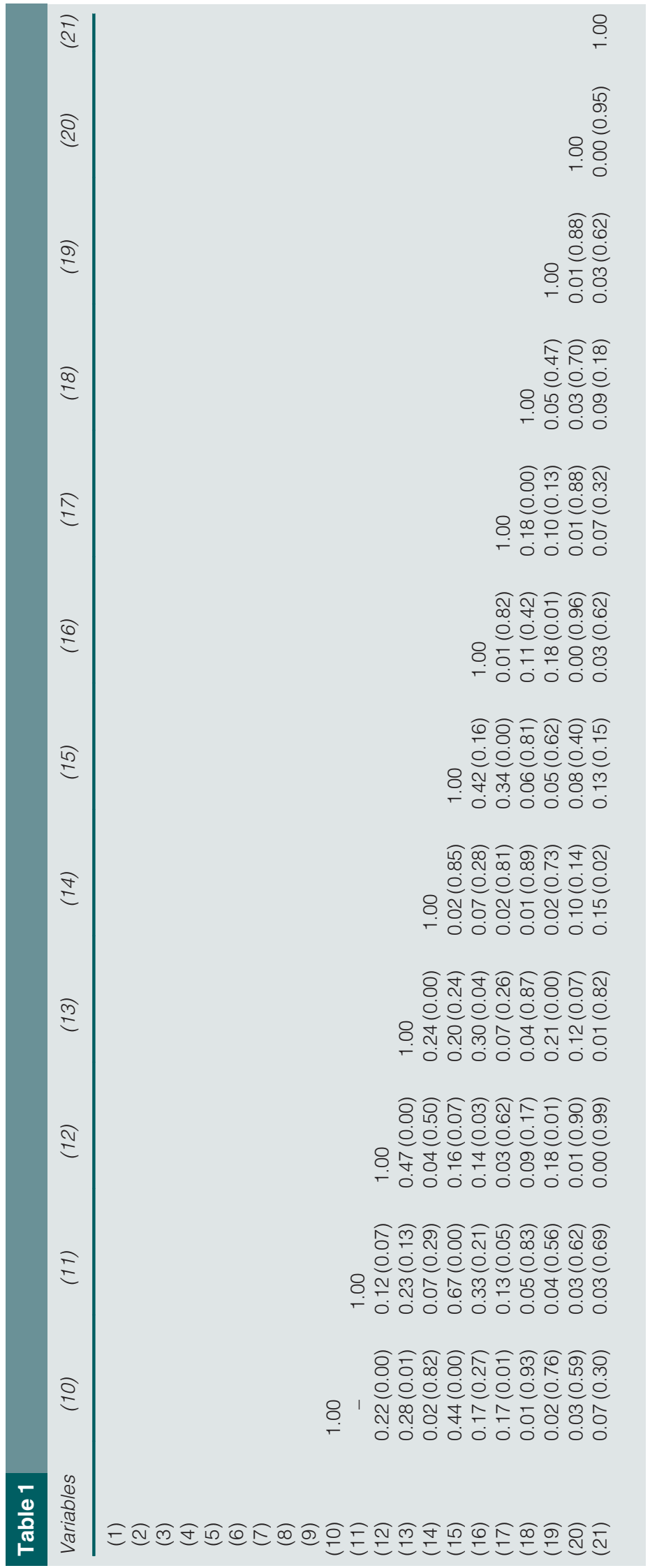


To exclude multi-collinearity, we did the variance inflation tests and we computed the condition indexes. Both were lower than the thresholds typically associated with multicollinearity problems (Belsley et al., 1980). We also took common method variance into account. During the data collection, some procedural remedies were implemented. For instance, the questionnaire was designed to minimize items ambiguity and social desirability bias in items' wording by adopting different scale types and number of scale points across questions, including reverse-worded items and alternating perceptive and non-perceptive questions (Podsakoff et al., 2012). Once concluded the data collection, we performed additional tests to control whether common method bias affected our results. To do so, we ran the Harman (1967) single factor test, which resulted in eight factors with eigenvalues greater than one, accounting for $62.24 \%$ of the total variance. The first factor explains only $17.96 \%$ of the variance. Therefore, the analysis excluded the presence of common method bias (Podsakoff and Organ, 1986).

In Table 2 the results of the models used to test $\mathrm{H} 1$ and $\mathrm{H} 2$ are reported; these include the four-step of Baron and Kenny (1986) to test mediation. Model 1 includes the baseline of control variables. Generally, firms in which the CEO has greater decision power ( $\beta=0.141$, $p<0.05)$ and operating in highly competitive $(\beta=0.233, p<0.01)$ and rapidly changing environments $(\beta=0.121, p<0.10)$ realize a significantly greater amount of opportunities. The number is instead significantly lower in subsidiaries controlled by foreign firms ( $\beta=$ $-0.515, p<0.01)$. Model 2 shows that family firms realize significantly fewer innovation opportunities compared to their non-family counterparts $(\beta=-0.284, p<0.10)$, thus supporting our baseline $\mathrm{H} 1$. To investigate the alleged mediating effect of the exchange of knowledge in the TMT, Model 3 tests whether there are differences between family and nonfamily firms in TMT knowledge exchange. The estimation reveals that Family firm is negatively and significantly related to TMT knowledge exchange ( $\beta=-0.331, p<0.05)$. Model 4 instead shows a positive and significant relation between the latter and the Realized innovation opportunities ( $\beta=0.178, p<0.01$ ). Finally, Model 5 tests the mediating effect by regressing Realized innovation opportunities against both Family firm and TMT knowledge exchange. While the coefficient of TMT knowledge exchange is still positive and significant ( $\beta=0.163, p<0.05$ ), the Family firm looses its significance. This indicates the presence of a full mediation, confirming $H 2$, which states that family firms realize fewer innovation opportunities because their TMT members exchange less knowledge. This result is confirmed by the absence of a moderating effect (Model 6) and by the more contemporary approaches we used. Specifically, Model 6 shows that TMT knowledge exchange does not moderate the relation between Family firms and Realized innovation opportunities. Moreover, following Hicks and Tingley (2011) and Sobel (1982), the average causal mediation effect is negative and significant, as well as the total effect while the direct effect of Family firm is not significant; the percentage of the total effect that is mediated by TMT knowledge exchange is equal to 0.176 . These are confirmed by the sensitivity analysis (Hicks and Tingley, 2011) and the most recent approach by Emsley and Liu (2013), which resulted in a not significant natural direct effect of Family firm while the natural indirect effect and the total effect are statistically significant. Altogether, these results confirm $\mathrm{H} 2$.

Table 3 reports the models we used to test $\mathrm{H} 3$ and $\mathrm{H} 4$ on the sub-sample of family firms, the dependent variable of which is TMT knowledge exchange. Model 7 is the baseline with only controls. TMT knowledge exchange is higher in larger firms $(\beta=0.198, p<0.10)$, subsidiaries controlled by foreign firms $(\beta=0.620, p<0.05)$ and in TMTs where the members trust each other more $(\beta=0.499, p<0.01)$. The exchange of knowledge is instead significantly lower in firms with greater growth in sales $(\beta=-0.144, p<0.01)$. As shown in Model 8, our H3 is not confirmed. Indeed, the relation between TMT composition and TMT knowledge exchange is not significant. The same holds for the direct effect of CEO search (Model 9). Interestingly, a significant moderating effect emerges between TMT composition and CEO search $(\beta=-1.333, p<0.01)$. This result is in line with $H 4$ arguing that, in family firms, the increase in the CEO's external search for innovation opportunities 


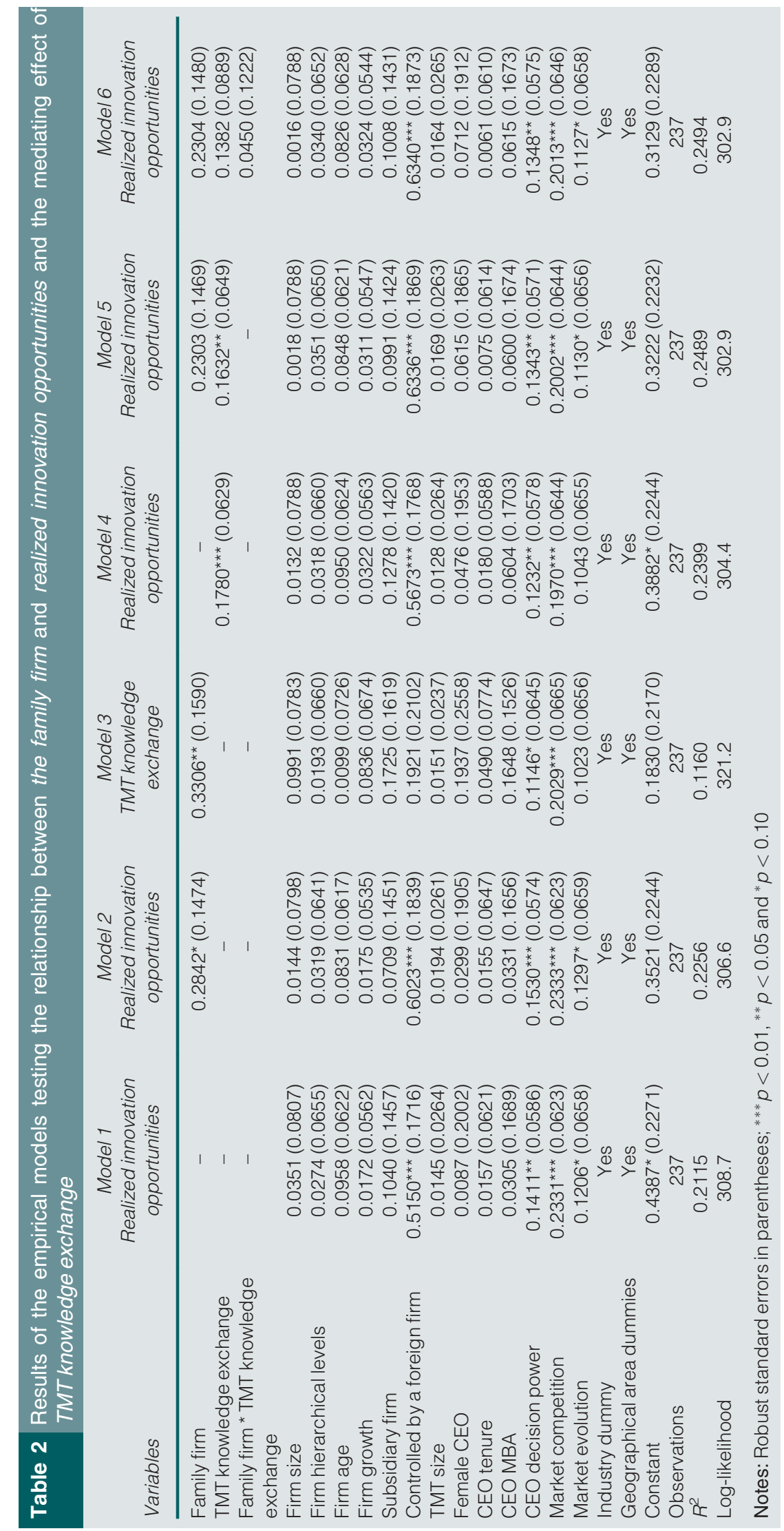


Table 3 Results of the empirical models testing, in family firms, the relationship between TMT composition anc TMT knowledge exchange and the moderating effect of the CEO search

\begin{tabular}{|c|c|c|c|c|}
\hline Variables & Model 7 & Model 8 & Model 9 & Model 10 \\
\hline TMT composition & - & $0.0417(0.3316)$ & $0.0412(0.3371)$ & $6.1033^{\star \star *}(1.7221)$ \\
\hline CEO search & - & - & $0.0041(0.1490)$ & $1.0570^{\star \star *}(0.3045)$ \\
\hline TMT composition * CEO search & - & - & - & $1.3333^{\star \star *}(0.3656)$ \\
\hline Firm size & $0.1984^{*}(0.1078)$ & $0.1972 *(0.1099)$ & $0.1972^{*}(0.1105)$ & $0.1322(0.1085)$ \\
\hline Firm hierarchical levels & $0.0339(0.0819)$ & $0.0338(0.0824)$ & $0.0339(0.0831)$ & $0.0086(0.0858)$ \\
\hline Firm age & $0.1019(0.0995)$ & $0.1009(0.1022)$ & $0.1004(0.0988)$ & $0.0852(0.0984)$ \\
\hline Firm growth & $0.1442^{\star \star \star}(0.0530)$ & $0.1451^{* * *}(0.0542)$ & $0.1450^{\star \star *}(0.0541)$ & $0.1158^{*}(0.0593)$ \\
\hline Subsidiary firm & $0.2051(0.2203)$ & $0.2063(0.2196)$ & $0.2062(0.2215)$ & $0.0866(0.2248)$ \\
\hline Controlled by a foreign firm & $0.6198^{\star *}(0.2795)$ & $0.6184^{\star *}(0.2819)$ & $0.6192^{\star *}(0.2778)$ & $0.5640 *(0.2858)$ \\
\hline TMT size & $0.0208(0.0330)$ & $0.0206(0.0330)$ & $0.0206(0.0335)$ & $0.0342(0.0331)$ \\
\hline CEOcentric TMT & $0.0477(0.2101)$ & $0.0500(0.2098)$ & $0.0489(0.2087)$ & $0.1923(0.2180)$ \\
\hline TMT trust & $0.4987^{\star \star *}(0.0774)$ & $0.5000^{* * *}(0.0773)$ & $0.5004^{\star * *}(0.0797)$ & $0.5077^{* * *}(0.0812)$ \\
\hline Family CEO & $0.0957(0.1993)$ & $0.0993(0.2045)$ & $0.0990(0.2090)$ & $0.1303(0.2081)$ \\
\hline Female CEO & $0.6519(0.4695)$ & $0.6567(0.4717)$ & $0.6555(0.4729)$ & $0.5565(0.4539)$ \\
\hline CEO tenure & $0.0077(0.0775)$ & $0.0080(0.0779)$ & $0.0080(0.0785)$ & $0.0140(0.0753)$ \\
\hline CEO MBA & $0.1592(0.2018)$ & $0.1563(0.2014)$ & $0.1569(0.2011)$ & $0.1063(0.2005)$ \\
\hline CEO decision power & $0.1553(0.1021)$ & $0.1529(0.1005)$ & $0.1527(0.0992)$ & $0.1617^{\star}(0.0949)$ \\
\hline Market competition & $0.1345(0.0954)$ & $0.1341(0.0953)$ & $0.1341(0.0958)$ & $0.1388(0.0933)$ \\
\hline Market evolution & $0.0558(0.0997)$ & $0.0577(0.1018)$ & $0.0574(0.1033)$ & $0.0973(0.0982)$ \\
\hline Industry dummies & Yes & Yes & Yes & Yes \\
\hline Geographical area dummies & Yes & Yes & Yes & Yes \\
\hline Constant & $0.4078(0.4039)$ & $0.4387(0.4738)$ & $0.4186(0.9159)$ & $5.4088^{\star \star *}(1.5964)$ \\
\hline Observations & 120 & 120 & 120 & 120 \\
\hline$R^{2}$ & 0.3897 & 0.3898 & 0.3898 & 0.4312 \\
\hline Log-likelihood & 0.390 & 0.390 & 0.390 & 0.431 \\
\hline
\end{tabular}

moderates the relationship between the ratio of non-family members in the TMT and TMT knowledge exchange. The Average Marginal Effect of TMT composition is positive (1.569 percentage points) and significant $(p<0.01)$ at the tenth percentile of $C E O$ search while it is not significant at the mean and then becomes negative and significant at the ninetieth percentile of CEO search $(-1.026$ percentage points, $p<0.01)$. This means that the increase in the ratio of non-family TMT members increases the knowledge exchange within the TMT when the CEO does not spend time to search for innovation opportunities outside the firm. The more CEO search increases, the more the positive effect of TMT composition on TMT knowledge exchange decreases, up to a point it becomes negative. Indeed, when the time spent by the CEO searching for innovation opportunities is high, the increase in the ratio of non-family TMT members negatively affects TMT knowledge exchange. Specifically, as shown in Figure 3 below, the relation between TMT composition and TMT knowledge exchange is positive and significant for values of CEO search lower than its 25th percentile while it is negative and significant for values of $C E O$ search higher than its seventieth percentile.

Robustness checks confirmed our findings. Specifically, to support the mediating effect of TMT knowledge exchange on the relation between Family firms and the realization of opportunities pertaining to innovation, we tested $\mathrm{H} 1$ and $\mathrm{H} 2$ by considering all types of opportunities presented to CEOs in the questionnaire. In so doing, a significant mediation did not emerge; this result can be reconducted to the fact that family and non-family firms do not differ in terms of realization of opportunities pertaining to changes in the organization (i.e. those that we excluded because not in line with our focus). This result supports our findings, demonstrating that knowledge exchange in the TMT allows family firms to realize more innovation opportunities only. This finding is also supported by the positive and significant relationship we found between TMT knowledge exchange and Realized innovation opportunities when considering the sample of only family firms. 


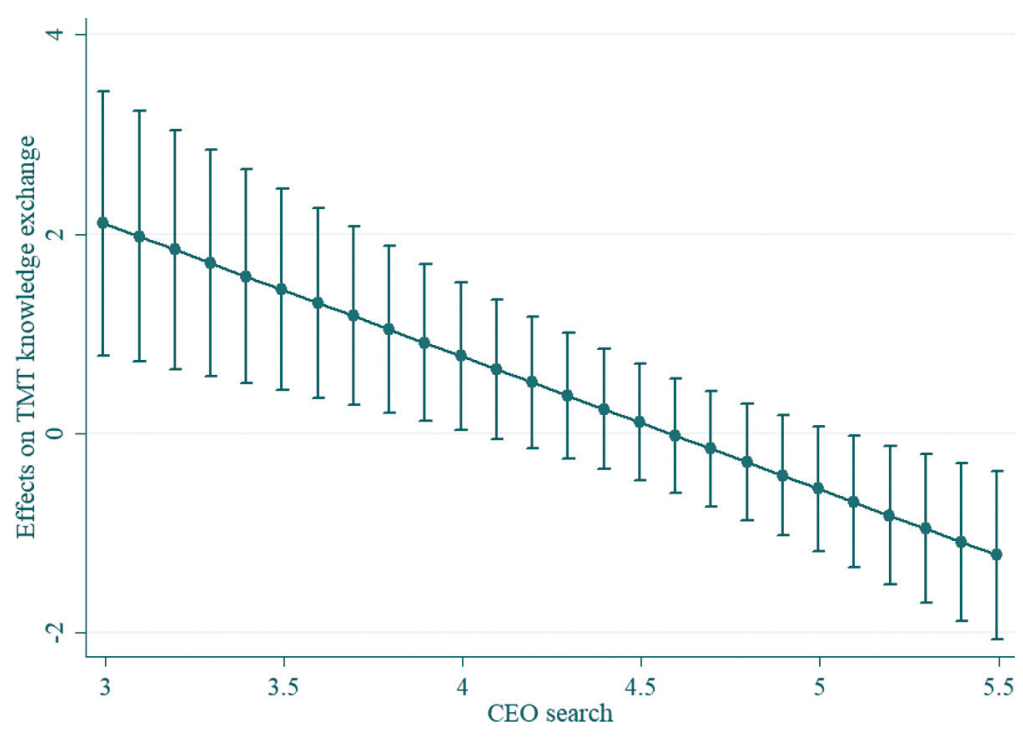

\section{Discussion}

Our study is targeted to understand the influences that the TMT exerts on knowledge management in pursuing innovation opportunity realization, specifically allowing family firms to keep up with their non-family counterparts. Our work indeed confirms that firms influenced by a family are typically at disadvantage, compared to firms not involving a family when dealing with innovation outcomes and especially the realization of innovation opportunities. This result is explained by the exchange of knowledge that characterizes family firms' TMT, which is significantly lower than in non-family firms. Such lower knowledge exchange, in turn, leads to the realization of fewer innovation opportunities. In the search for the reason behind the lower exchange of knowledge, we found that neither the composition of the TMT in terms of family vs non-family members nor the CEO search have a direct effect. Interestingly, their combination matters. Indeed, when the search for innovation opportunities outside the firm operated by the CEO is limited, the increase in the number of non-family members in the TMT fosters the exchange of knowledge within the team. The more the CEO spends time in searching for external innovation opportunities, the more this positive effect reduces up to progressively becoming negative when CEO search is high, as depicted in Figure 3. This result may be explained by the combination of CEO outward orientation and the lack of external social network overlap between family and non-family TMT members. The increase of non-family members in the TMT allows the team to socialize with external contacts from diverse sets of groups, that go beyond the mere family's contacts. By interacting with a broader range of non-redundant contacts, the TMT members access more novel, timely and diverse knowledge, which they need then to exchange within the TMT. Coherently with the mechanisms of absorptive capacity, this knowledge is thus externally acquired, assimilated and transformed by the TMT through exchange and then exploited in the form of realized innovation opportunities. Nevertheless, an excessive CEO search for external knowledge has the counterproductive effect of preempting this exchange of knowledge within the TMT. On the one hand, the combined outward orientation of the CEO and of non-family TMT members - who all devote time to search for novel innovation opportunities in sparse networks of contacts - undermines the TMT knowledge 
exchange, limiting its assimilation and transformation, and thus compromising the possibility to realize innovation opportunities. On the other hand, even when the search activity exerted by the CEO could contribute to access to further external knowledge beyond that accessible by the TMT, the family firms' tendency toward centralization may lead their CEO to strongly rely on the knowledge autonomously assimilated and transformed to decide on the realization of innovation opportunities, without involving the TMT. It thus follows that the TMT composition and CEO search should not be considered in isolation, but their configuration is determinant for family firms to acquire, assimilate and transform external knowledge and exploit it to realize innovation opportunities.

Overall, our study offers important contributions to the current understanding of knowledge management and innovation opportunity realization of family firms, with particular attention devoted to TMT behavior and characteristics. First, we extend the knowledge-based perspective of family firms' innovation (Chirico and Salvato, 2016; Cabrera-Suárez et al., 2018) by exploring how knowledge is acquired, assimilated, transformed and exploited by the TMT. Such perspective contributes to deepening our understanding about absorptive capacity (Cohen and Levinthal, 1990) in the context of family firms (Brinkerink, 2018; Kotlar et al., 2020). Prior research has argued that family ownership influences the hierarchical structure and informal social relations within the firm (Cannella et al., 2015; Patel and Cooper, 2014), thereby setting the constraints to the knowledge that can be acquired, assimilated, transformed and exploited (Sammarra and Biggiero, 2008). Following this line of inquiry, we complement the current understanding of absorptive capacity in family firms (Brinkerink, 2018) by examining the effect that the organizational design of a firm, in relation to TMT behavior and characteristics, exerts on knowledge acquisition and assimilation through external networks of contacts, transformation and exploitation within the TMT to realize innovation opportunities. With our endeavor, we address the call for quantitative studies to test the relationship between family ownership and absorptive capacity through the mechanisms of power concentration (Kotlar et al., 2020) and extend it by capturing the behavior and characteristics of family firms' TMT, identifying important contingency factors that shape the ability of family firms to do more with less (Duran et al., 2016).

As mentioned above, we found that family firms are characterized by low TMT knowledge exchange, which, in turn, limits their innovation opportunity realization. Therefore, we decided to delve deeper into the contingency factors that allow family firms to increase their TMT knowledge exchange. In so doing, we made the first attempt to examine TMT characteristics through an approach able to grasp the interaction of organizational design and searching activities. By identifying the presence of non-family members in the TMT as the driver of higher knowledge exchange we contribute to the literature on family firm organizational design. While prior research has shown that the TMT organizational configuration adopted by family firms leads to lower opportunity exploitation (De Massis et al., 2020), the mechanisms through which knowledge management within the TMT relates to innovation were mostly overlooked so far. Research has identified elements of TMT diversity - gender, generation, goals - as drivers of creativity in the upper echelons of family firms (Röd, 2019; Kammerlander et al., 2020); however, the behavior of the TMT was only theoretically inferred as a mechanism connecting empirically captured TMT characteristics and innovation outcomes (Kraiczy et al., 2014). Our evidence extends the current understanding of TMT and knowledge management in family firms by putting TMT behavior under the spotlight through the empirical examination of TMT knowledge exchange and CEO search, thereby examining the interaction of TMT structure and behavior on family firm innovation opportunity realization. Digging deeper into the interplay between TMT composition and CEO search (Cao et al., 2010), we were also able to combine an internal perspective related to the level of TMT knowledge exchange with an external perspective that grasps the network of contacts accessible by the TMT members and CEO search activities. While the ability of family firms to develop trustful and long-lasting connections with external stakeholders is considered one of their main strengths (Miller and Le Breton-Miller, 2005), few 
studies have so far combined the internal and external perspective in examining how relationships affect family firm's knowledge management and innovation performance (e.g., Rondi et al, 2021). In so doing, we unveil a compensating mechanism operated by the CEO that inhibits the ability of family firms with many non-family TMT members to exchange knowledge useful to realize innovation opportunities. In this regard, by considering CEO time management as a proxy of the CEO search, we offer implications to the nascent literature on CEO time management (Bandiera et al., 2011; Rovelli, 2020).

Our study offers also insights to family business practitioners. In light of our results, TMT members and family firm leaders should invest in mechanisms aimed at fostering the exchange of knowledge in the TMT to realize a higher number of innovation opportunities. Moreover, family business consultants are informed from our study about the importance of considering TMT behaviors and characteristics (including CEO behavior, being the CEO a member of the TMT) in concert rather than in isolation. In fact, while the increase in nonfamily TMT members is needed to foster knowledge exchange in the team, it turns to be harmful when the commitment of the CEO in searching for innovation opportunities outside the firm is too high.

As with any other study, our work is not devoid of limitations, which give rise to interesting opportunities for future research. Our work suffers from limitations in the empirical implementation. First, it is limited to one country, raising potential issues regarding its generalizability and we thus welcome additional tests in other empirical settings to validate our findings in alternative contexts. Second, we used a cross-sectional database. Nevertheless, research on family firms' absorptive capacity is calling for studies able to grasp its variance over time; in this sense, longitudinal studies might allow a deeper understanding of the investigated time-varying effects of family ownership on absorptive capacity (Kotlar et al., 2020). A longitudinal perspective would also allow examining potential causality in the behavior of the CEO and TMT composition. Potentially, an outwardoriented CEO (especially a family CEO) who devotes time to collect information may not feel the need for non-family managers to provide further knowledge, and therefore, prefer not to hire externals. Third, we used a set of proxies for measuring absorptive capacity. While we are confident about the quality of our data and measures, future research might replicate our study by using alternative measures (see, for example, Jiménez-Barrionuevo et al., 2011). Fourth, while research in family business innovation has highlighted distinctive behaviors of the TMT in relation to exploration, exploitation and ambidexterity (Röd, 2019; Kammerlander et al., 2020), our empirical investigation does not take into account the degree of innovativeness of the opportunities realized. Fifth, we assume and find that the more the non-family members in the TMT, the better for TMT knowledge exchange. Although in our study we assume the TMT as a united group, we acknowledge that TMT members may cluster in subgroups due to specific characteristics as family membership, keeping information private to the family clique for preserving secrecy and fear of disclosing information with non-family members (Stewart and Hitt, 2012; Ward, 1997). Under such circumstances, knowledge circulates only among family members, thereby preventing nonfamily members to observe and benefit from TMT knowledge exchange. Therefore, future studies adopting qualitative methods are needed to explore how knowledge exchange actually occurs in the TMT and the role of TMT diversity in knowledge exchange within subgroups.

In terms of conceptual limitations, whereas the TMT is the firms' locus of the decisionmaking (Amason, 1996; Collins and Clark, 2003) and adopting a TMT perspective to explain family firms' realization of innovation opportunities adds an important but relatively new perspective to the family business and knowledge management literature, a broader view might provide further explanations to the highlighted gap between family and non-family firms. For instance, exploring the exchange of innovation and knowledge throughout the entire hierarchical chain or whether and how the board of directors intervenes might help in 
this regard. Moreover, family firms often rely on tacit knowledge as the source of competitive advantage. Such tacit knowledge is cultivated and preserved within organizational boundaries through low turnover (Rondi et al., 2021). Tacit knowledge is based on intensive communication and interactions; however, we are recently witnessing dramatic changes due to the pandemic circumstances that are affecting the way people within organizations in general and family firms, in particular, communicate and interact e.g. remote working, digitalization [3] (De Massis and Rondi, 2020). We join the call for future studies intended to understand how remote working, digitalization and more in general changes in organizational design are impacting the knowledge exchange within the TMT of family and non-family firms and how such changes affect innovation opportunity realization. Finally, following recent developments in the management literature (Bandiera et al., 2011; Rovelli, 2020), our focus on the CEO behavior in terms of time spent in searching for opportunities brings interesting insights and might be a stimulus to dedicate more research on the role of time management in the family business. Future research could further delve into the compensating mechanism of the CEO search that inhibits the ability of family firms with many non-family TMT members to exchange knowledge useful to realize innovation opportunities. In so doing, future studies might examine not only the time devoted but also other aspects as the content of acquired knowledge and the type of relationships that allow the CEO to identify such knowledge, which is likely to shape the exchange within the TMT. By undertaking a temporal perspective, scholars should examine whether the CEO needs to often renew the network of contacts to gather novel knowledge and avoid redundancy or if he/she is prone to introduce other TMT members to enlarge the firm's network rather than keeping such personal contacts. Moreover, although we did not find any difference in having a family or a non-family CEO, other CEO characteristics and behaviors might come into play in favoring the exchange of knowledge in family firms and their TMTs. A case in point is CEO's individual characteristics, such as their culture, personality traits, educational background and work experience.

In a similar vein, in our paper, we focus on a single TMT characteristic, namely, its composition. While the composition of the TMT in terms of family involvement is one of the governance characteristics considered as more influential on the family firms' behavior (Tabor et al., 2018), we invite scholars to consider other aspects, which may give rise to diversity in the team and affect interactions and knowledge exchange among its members (e.g. members' tenure, age, cultural background, gender). An interesting venue for future research concerns the emotional aspects related to the TMT, which has been already conceptually identified as determinants of a firm's absorptive capacity (Kotlar et al., 2020). This would allow to identify the effect of emotional attachment or to combine emotional and social aspects adopting a socioemotional wealth scale (see, for example, Debicki et al., 2016) to capture their influence on TMT behavior in terms of knowledge exchange and the related effect on innovation opportunity realization. Alternatively, a broader view might consider the collaborative innovation initiatives (Feranita et al., 2017) undertaken by the organization and related TMT dynamics that might lead family firms to exchange knowledge beyond the organizational boundaries and, in turn, realize opportunities through open innovation (e.g., Rondi et al., 2021).

\section{Conclusions}

Embracing a knowledge-based perspective to examine family firm innovation, in this study we test our hypotheses on 237 surveyed Italian firms, 120 of which are family firms. Through our empirical investigation, we found support for the hypothesized lower level of innovation opportunity realization in the family than in non-family firms due to the mediation of lower TMT knowledge exchange. Moreover, we unveil the need for a holistic examination of family firms' heterogeneity in terms of TMT characteristics - in our case TMT composition - and CEO search as the driver of TMT knowledge exchange. 


\section{Notes}

1 We consider CEO behavior as part of TMT behavior because the CEO is a member of the TMT.

2 The TMT includes the CEO.

3 We are grateful to one of the two anonymous reviewers for raising our attention toward this important aspect.

\section{References}

Ahuja, G., Lampert, C.M. and Tandon, V. (2008), "Moving beyond Schumpeter: management research on the determinants of technological innovation", Academy of Management Annals, Vol. 2 No. 1, pp. 1-98.

Alguezaui, S. and Filieri, R. (2010), "Investigating the role of social capital in innovation: sparse versus dense network", Journal of Knowledge Management, Vol. 14 No. 6, pp. 891-909.

Amason, A.C. (1996), "Distinguishing the effects of functional and dysfunctional conflict on strategic decision making: resolving a paradox for top management teams", Academy of Management Journal, Vol. 39 No. 1, pp. 123-148.

Andrews, D., Nonnecke, B. and Preece, J. (2003), "Electronic survey methodology: a case study in reaching hard-to-involve internet users", International Journal of Human-Computer Interaction, Vol. 16 No. 2, pp. 185-210.

Baldwin, C.Y. and Clark, K.B. (2000), Design Rules, MIT Press, Cambridge, MA.

Bandiera, O., Guiso, L., Prat, A. and Sadun, R. (2011), "What do CEOs do?".

Barney, J.B., Foss, N.J. and Lyngsie, J. (2018), "The role of senior management in opportunity formation: direct involvement or reactive selection?”, Strategic Management Journal, Vol. 39 No. 5, pp. 1325-1349.

Baron, R.M. and Kenny, D.A. (1986), "The moderator-mediator variable distinction in social psychological research: conceptual, strategic and statistical considerations", Journal of Personality and Social Psychology, Vol. 51 No. 6, pp. 1173-1182.

Belsley, D., Kuh, E. and Welsch, R. (1980), Regression Diagnostics: Influential Data and Sources of Collinearity, Wiley, New York, NY

Brinkerink, J. (2018), "Broad search, deep search, and the absorptive capacity performance of family and nonfamily firm R\&D", Family Business Review, Vol. 31 No. 3, pp. 295-317.

Brinkerink, J., Rondi, E., Benedetti, C. and Arzubiaga, U. (2020), "Family business or business family? Organizational identity elasticity and strategic responses to disruptive innovation", Journal of Family Business Strategy, Vol. 11 No. 4, p. 100360.

Burke, M.J. and Dunlap, W.P. (2002), "Estimating interrater agreement with the average deviation index: a user's guide", Organizational Research Methods, Vol. 5 No. 2, pp. 159-172.

Cabrera-Suárez, K., De Saá-Pérez, P. and García-Almeida, D. (2001), "The succession process from a resource-and knowledge-based view of the family firm", Family Business Review, Vol. 14 No. 1, pp. 37-48.

Cabrera-Suárez, M.K., García-Almeida, D.J. and De Saá-Pérez, P. (2018), "A dynamic network model of the successor's knowledge construction from the resource-and knowledge-based view of the family firm", Family Business Review, Vol. 31 No. 2, pp. 178-197.

Calabrò, A., Vecchiarini, M., Gast, J., Campopiano, G., De Massis, A. and Kraus, S. (2019), "Innovation in family firms: a systematic literature review and guidance for future research", International Journal of Management Reviews, Vol. 21 No. 3, pp. 317-355.

Cannella, A.A., Jr, Jones, C.D. and Withers, M.C. (2015), "Family-versus lone-founder-controlled public corporations: social identity theory and boards of directors", Academy of Management Journal, Vol. 58 No. 2, pp. 436-459.

Cao, Q., Simsek, Z. and Zhang, H. (2010), "Modelling the joint impact of the CEO and the TMT on organizational ambidexterity", Journal of Management Studies, Vol. 47 No. 7, pp. 1272-1296.

Cardinal, L.B. (2001), "Technological innovation in the pharmaceutical industry: the use of organizational control in managing research and development”, Organization Science, Vol. 12 No. 1, pp. 19-36. 
Carney, M. (2005), "Corporate governance and competitive advantage in family-controlled firms", Entrepreneurship Theory and Practice, Vol. 29 No. 3, pp. 249-265.

Chirico, F. (2008), "Knowledge accumulation in family firms: evidence from four case studies", International Small Business Journal: Researching Entrepreneurship, Vol. 26 No. 4, pp. 433-462.

Chirico, F. and Salvato, C. (2008), "Knowledge integration and dynamic organizational adaptation in family firms", Family Business Review, Vol. 21 No. 2, pp. 169-181.

Chirico, F. and Salvato, C. (2016), "Knowledge internalization and product development in family firms: when relational and affective factors matter", Entrepreneurship Theory and Practice, Vol. 40 No. 1, pp. 201-229.

Chrisman, J.J., Chua, J.H., Pearson, A.W. and Barnett, T. (2012), "Family involvement, family influence, and family-centered non-economic goals in small firms", Entrepreneurship Theory and Practice, Vol. 36 No. 2, pp. 267-293.

Ciarrochi, J. and Forgas, J.P. (2000), "The pleasure of possessions: affective influences and personality in the evaluation of consumer items", European Journal of Social Psychology, Vol. 30 No. 5, pp. 631-649.

Claver-Cortés, E., Zaragoza-Sáez, P. and Pertusa-Ortega, E. (2007), "Organizational structure features supporting knowledge management processes", Journal of Knowledge Management, Vol. 11 No. 4.

Cohen, W.M. and Levinthal, D.A. (1990), "Absorptive capacity: a new perspective on learning and innovation”, Administrative Science Quarterly, Vol. 35 No. 1, pp. 128-152.

Collins, D. (2003), "Pretesting survey instruments: an overview of cognitive methods", Quality of Life Research, Vol. 12 No. 3, pp. 229-238.

Collins, C.J. and Clark, K.D. (2003), "Strategic human resource practices, top management team social networks, and firm performance: the role of human resource practices in creating organizational competitive advantage", Academy of Management Journal, Vol. 46 No. 6, pp. 740-751.

Cruz, C., Gomez-Mejia, L.R. and Becerra, M. (2010), "Perceptions of benevolence and the design of agency contracts: CEO-TMT relationships in family firms", Academy of Management Journal, Vol. 53 No. 1, pp. 69-89.

D'Allura, G.M. (2019), "The leading role of the top management team in understanding family firms: past research and future directions", Journal of Family Business Strategy, Vol. 10 No. 2, pp. 87-104.

Damanpour, F. (1991), "Organizational innovation: a meta-analysis of effects of determinants and moderators", Academy of Management Journal, Vol. 34 No. 3, pp. 555-590.

Danneels, E. (2015), "Survey measures of first- and second-order competences", Strategic Management Journal, Vol. 37 No. 10, pp. 2174-2188.

Darroch, J. (2005), "Knowledge management, innovation and firm performance", Journal of Knowledge Management, Vol. 9 No. 3.

De Massis, A., Eddleston, K.A. and Rovelli, P. (2020), "Entrepreneurial by design: how organizational design affects family and nonfamily firms' opportunity exploitation", Journal of Management Studies, Vol. 58 No. 1.

De Massis, A., Frattini, F., Kotlar, J., Petruzzelli, A.M. and Wright, M. (2016), "Innovation through tradition: lessons from innovative family businesses and directions for future research", Academy of Management Perspectives, Vol. 30 No. 1, pp. 93-116.

De Massis, A., Frattini, F. and Lichtenthaler, U. (2013), "Research on technological innovation in family firms: present debates and future directions", Family Business Review, Vol. 26 No. 1, pp. 10-31.

De Massis, A. and Rondi, E. (2020), "COVID-19 and the future of family business research", Journal of Management Studies, Vol. 57 No. 8, pp. 1727-1731.

Debicki, B.J., Kellermanns, F.W., Chrisman, J.J., Pearson, A.W. and Spencer, B.A. (2016), "Development of a socioemotional wealth importance (SEWi) scale for family firm research", Journal of Family Business Strategy, Vol. 7 No. 1, pp. 47-57.

Del Giudice, M., Della Peruta, M.R. and Carayannis, E. (2010), Knowledge and the Family Business, Springer.

Dillman, D.A. (2000), Mail and Internet Surveys: The Tailored Design Method, Wiley, New York, NY. 
Döring, H. and Witt, P. (2020), "Knowledge management in family businesses: empirical evidence from Germany", Knowledge Management Research \& Practice, Vol. 18 No. 2, pp. 175-187.

Duran, P., Kammerlander, N., Van Essen, M. and Zellweger, T. (2016), "Doing more with less: innovation input and output in family firms", Academy of Management Journal, Vol. 59 No. 4, pp. 1224-1264.

Emsley, R. and Liu, H. (2013), PARAMED: Stata Module to Perform Causal Mediation Analysis Using Parametric Regression Models, Boston College Department of Economics, 26 Apr 2013.

Feltham, T.S., Feltham, G. and Barnett, J.J. (2005), "The dependence of family businesses on a single decision-maker”, Journal of Small Business Management, Vol. 43 No. 1, pp. 1-15.

Feranita, F., Kotlar, J. and De Massis, A. (2017), "Collaborative innovation in family firms: past research, current debates and agenda for future research", Journal of Family Business Strategy, Vol. 8 No. 3, pp. 137-156.

Fleming, L. and Sorenson, O. (2001), "Technology as a complex adaptive system: evidence from patent data", Research Policy, Vol. 30 No. 7, pp. 1019-1039.

Foss, N.J., Lyngsie, J. and Zahra, S.A. (2013), "The role of external knowledge sources and organizational design in the process of opportunity exploitation”, Strategic Management Journal, Vol. 34 No. 12 , pp. $1453-1471$

Foss, N.J., Lyngsie, J. and Zahra, S.A. (2015), "Organizational design correlates of entrepreneurship: the roles of decentralization and formalization for opportunity discovery and realization", Strategic Organization, Vol. 13 No. 1, pp. 32-60.

Garcés-Galdeano, L., Larraza-Kintana, M., Cruz, C. and Contín-Pilart, I. (2017), "Just about money? CEO satisfaction and firm performance in small family firms", Small Business Economics, Vol. 49 No. 4, pp. 825-839.

Garud, R., Tuertscher, P. and Van de Ven, A.H. (2013), "Perspectives on innovation processes", Academy of Management Annals, Vol. 7 No. 1, pp. 775-819.

Goel, S. and Jones, R.J. III (2016), "Entrepreneurial exploration and exploitation in family business: a systematic review and future directions", Family Business Review, Vol. 29 No. 1, pp. 94-120.

Goh, P.C. (2005), "Intellectual capital performance of commercial banks in Malaysia", Journal of Intellectual Capital.

Gómez-Mejía, L.R., Haynes, K.T., Núñez-Nickel, M., Jacobson, K.J. and Moyano-Fuentes, J. (2007), "Socioemotional wealth and business risks in family-controlled firms: evidence from Spanish olive oil mills", Administrative Science Quarterly, Vol. 52 No. 1, pp. 106-137.

Graham, J.R., Harvey, C.R. and Puri, M. (2013), "Managerial attitudes and corporate actions", Journal of Financial Economics, Vol. 109 No. 1, pp. 103-121.

Grant, R.M. (1996), "Toward a knowledge-based theory of the firm", Strategic Management Journal, Vol. 17, pp. 109-122.

Hansen, M.T., Mors, M.L. and Løvås, B. (2005), "Knowledge sharing in organizations: multiple networks, multiple phases", Academy of Management Journal, Vol. 48 No. 5, pp. 776-793.

Harman, H.H. (1967), Modern Factor Analysis, University of Chicago Press, Chicaho, IL.

Harveston, P.D., Davis, P.S. and Lyden, J.A. (1997), "Succession planning in family business. The impact of owner gender", Family Business Review, Vol. 10 No. 4, pp. 373-396.

Hicks, R. and Tingley, D. (2011), "Causal mediation analysis", The Stata Journal: Promoting Communications on Statistics and Stata, Vol. 11 No. 4, pp. 605-619.

Jiménez-Barrionuevo, M.M., García-Morales, V.J. and Molina, L.M. (2011), "Validation of an instrument to measure absorptive capacity", Technovation, Vol. 31 Nos 5/6, pp. 190-202.

Kammerlander, N. and Ganter, M. (2015), "An attention-based view of family firm adaptation to discontinuous technological change: exploring the role of family CEOs' noneconomic goals", Journal of Product Innovation Management, Vol. 32 No. 3, pp. 361-383.

Kammerlander, N., Patzelt, H., Behrens, J. and Röhm, C. (2020), "Organizational ambidexterity in familymanaged firms: the role of family involvement in top management", Family Business Review, Vol. 33 No. 4, pp. 393-423. 
Katila, R. (2002), "New product search over time: past ideas in their prime?", Academy of Management Journal, Vol. 45 No. 5, pp. 995-1010.

Katila, R. and Ahuja, G. (2002), "Something old, something new: a longitudinal study of search behavior and new product introduction", Academy of Management Journal, Vol. 45 No. 6, pp. 1183-1194

Kostopoulos, K., Papalexandris, A., Papachroni, M. and Ioannou, G. (2011), "Absorptive capacity, innovation, and financial performance”, Journal of Business Research, Vol. 64 No. 12, pp. 1335-1343.

Kotlar, J., De Massis, A., Frattini, F. and Kammerlander, N. (2020), "Motivation gaps and implementation traps: the paradoxical and time-varying effects of family ownership on firm absorptive capacity", Journal of Product Innovation Management, Vol. 37 No. 1, pp. 2-25.

Kraiczy, N.D., Hack, A. and Kellermanns, F.W. (2014), "New product portfolio performance in family firms", Journal of Business Research, Vol. 67 No. 6, pp. 1065-1073.

Kriauciunas, A., Parmigiani, A. and Rivera-Santos, M. (2011), "Leaving our comfort zone: integrating established practices with unique adaptations to conduct survey-based strategy research in nontraditional contexts", Strategic Management Journal, Vol. 32 No. 9, pp. 994-1010.

Lenox, M. and King, A. (2004), "Prospects for developing absorptive capacity through internal information provision", Strategic Management Journal, Vol. 25 No. 4, pp. 331-345.

Ling, Y. and Kellermanns, F.W. (2010), "The effects of family firm specific sources of TMT diversity: the moderating role of information exchange frequency", Journal of Management Studies, Vol. 47 No. 2, pp. 322-344.

Mahto, R.V., Davis, P.S. and Khanin, D. (2010), "Continuation commitment: family's commitment to continue the family business", Journal of Family and Economic Issues, Vol. 35 No. 2, pp. 278-289.

Mazzelli, A., De Massis, A., Petruzzelli, A.M., Del Giudice, M. and Khan, Z. (2019), "Behind ambidextrous search: the microfoundations of search in family and non-family firms", Long Range Planning, p. 101882.

Miller, D. and Le Breton-Miller, I. (2005), Managing for the Long Run: Lessons in Competitive Advantage from Great Family Businesses, Harvard Business Press.

Miller, D., Minichilli, A. and Corbetta, G. (2013), "Is family leadership always beneficial?", Strategic Management Journal, Vol. 34 No. 5, pp. 553-571.

Minichilli, A., Corbetta, G. and MacMillan, I.C. (2010), "Top management teams in family-controlled companies: 'familiness', 'faultlines', and their impact on financial performance”, Journal of Management Studies, Vol. 47 No. 2, pp. 205-222.

Nadler, D. and Tushman, M.L. (1997), Competing by Design: The Power of Organizational Architecture, Oxford University Press, New York, NY.

Nonaka, I. and Takeuchi, H. (1995), The Knowledge-Creating Company: How Japanese Companies Create the Dynamics of Innovation, Oxford University Press.

Oh, H., Chung, M.H. and Labianca, G. (2004), "Group social capital and group effectiveness: the role of informal socializing ties", Academy of Management Journal, Vol. 47 No. 6, pp. 860-875.

Oh, H., Labianca, G. and Chung, M.H. (2006), "A multilevel model of group social capital", Academy of Management Review, Vol. 31 No. 3, pp. 569-582.

Patel, P.C. and Cooper, D. (2014), "Structural power equality between family and non-family TMT members and the performance of family firms", Academy of Management Journal, Vol. 57 No. 6, pp. 1624-1649.

Podsakoff, P.M. and Organ, D.W. (1986), "Self-reports in organizational research: problems and prospects", Journal of Management, Vol. 12 No. 4, pp. 531-544.

Podsakoff, P.M., MacKenzie, S.B. and Podsakoff, N.P. (2012), "Sources of method bias in social science research and recommendations on how to control it", Annual Review of Psychology, Vol. 63 No. 1, pp. 539-569.

Portes, A. and Sensenbrenner, J. (1993), "Embeddedness and immigration: notes on the social determinants of economic action", American Journal of Sociology, Vol. 98 No. 6, pp. 1320-1350.

Poterba, J.M. and Summers, L.H. (1995), "A CEO survey of US companies' time horizons and hurdle rates", Sloan Management Review, Vol. 37 No. 1, pp. 43-53. 
Röd, I. (2019), "TMT diversity and innovation ambidexterity in family firms", Journal of Family Business Management, Vol. 9 No. 4.

Rondi, E., De Massis, A. and Kraus, S. (2021), "Servitization through open service innovation in family firms: exploring the ability-willingness paradox", Journal of Business Research, Vol. 135, pp. 436-444.

Rondi, E., Uberbacher, R., von Schlenk-Barnsdorf, L., De Massis, A. and Hulsbeck, M. (2021), "One for all, all for one: a mutual gains perspective on HRM and innovation management practices in family firms", Journal of Family Business Strategy.

Rothaermel, F.T. and Hess, A.M. (2007), "Building dynamic capabilities: innovation driven by individual-, firm-, and network-level effects”, Organization Science, Vol. 18 No. 6, pp. 898-921.

Rovelli, P. (2017), "Organizing at the top of the hierarchy: an inquiry into delegation of decisions", Politecnico di Milano, available at: www.politesi.polimi.it/handle/10589/131415

Rovelli, P. (2020), "I am stuck in meetings': understanding the relation of CEO time management with TMT size and gender diversity", European Management Journal, Vol. 38 No. 5.

Rovelli, P. and Rossi-Lamastra, C. (2018), "Collecting data on TMT's organizational design: good practices from the StiMa project", Economia e Politica Industriale, Vol. 45 No. 2, pp. 175-213.

Rovelli, P., Rossi-Lamastra, C., Longoni, A. and Cagliano, R. (2020), "TMT organizational configurations and opportunity realization in established firms: an exploratory analysis", Long Range Planning, Vol. 53 No. 3, p. 101972.

Russo, M.V. and Harrison, N.S. (2005), "Organizational design and environmental performance: clues from the electronics industry", Academy of Management Journal, Vol. 48 No. 4, pp. 582-593.

Sammarra, A. and Biggiero, L. (2008), "Heterogeneity and specificity of inter-firm knowledge flows in innovation networks", Journal of Management Studies, Vol. 45 No. 4, pp. 800-829.

Simons, T.L. and Peterson, R.S. (2000), "Task conflict and relationship conflict in top management teams: the pivotal role of intragroup trust”, Journal of Applied Psychology, Vol. 85 No. 1, pp. 102-111.

Simsek, Z. (2007), "CEO tenure and organizational performance: an intervening model", Strategic Management Journal, Vol. 28 No. 6, pp. 653-662.

Simsek, Z., Veiga, J.F., Lubatkin, M.H. and Dino, R.N. (2005), "Modeling the multilevel determinants of top management team behavioral integration", Academy of Management Journal, Vol. 48 No. 1, pp. 69-84.

Sirmon, D.G., Hitt, M.A., Ireland, R.D. and Gilbert, B.A. (2011), "Resource orchestration to create competitive advantage: breadth, depth, and life cycle effects", Journal of Management, Vol. 37 No. 5 , pp. 1390-1412.

Sobel, M.E. (1982), "Asymptotic confidence intervals for indirect effects in structural equation models", Sociological Methodology, Vol. 13 No. 1982, pp. 290-312.

Stewart, A. and Hitt, M.A. (2012), "Why can't a family business be more like a nonfamily business? Modes of professionalization in family firms", Family Business Review, Vol. 25 No. 1, pp. 58-86.

Tabor, W., Chrisman, J.J., Madison, K. and Vardaman, J.M. (2018), "Nonfamily members in family firms: a review and future research agenda", Family Business Review, Vol. 31 No. 1, pp. 54-79.

van Doorn, S., Heyden, M.L. and Volberda, H.W. (2017), "Enhancing entrepreneurial orientation in dynamic environments: the interplay between top management team advice-seeking and absorptive capacity", Long Range Planning, Vol. 50 No. 2, pp. 134-144.

Ward, J.L. (1997), "Growing the family business: special challenges and best practices", Family Business Review, Vol. 10 No. 4, pp. 323-337.

Woodfield, P. and Husted, K. (2017), "Intergenerational knowledge sharing in family firms: case-based evidence from the New Zealand wine industry", Journal of Family Business Strategy, Vol. 8 No. 1, pp. 57-69.

Yli-Renko, H., Autio, E. and Sapienza, H.J. (2001), "Social capital, knowledge acquisition, and knowledge exploitation in young technology-based firms", Strategic Management Journal, Vol. 22 Nos 6/7, pp. 587-613.

Zahra, S.A. and George, G. (2002), "Absorptive capacity: a review, reconceptualization, and extension", Academy of Management Review, Vol. 27 No. 2, pp. 185-203. 
Zahra, S.A., Neubaum, D.O. and Larrañeta, B. (2007), "Knowledge sharing and technological capabilities: the moderating role of family involvement", Journal of Business Research, Vol. 60 No. 10, pp. 1070-1079.

\section{Appendix. Representativeness, non-response bias and reliability of the survey sample}

To assess the quality of the survey collected data, we performed several tests, which confirmed the representativeness, the absence of non-response bias and the reliability of CEOs' answers.

To test the representativeness of the sample with respect to the population we considered the three dimensions used to stratify it. The chi-squared $\left(\chi^{2}\right)$ tests revealed that the sample is representative with respect to the distribution of firms by industry $\left(\chi^{2}(1)=2.058 ; p\right.$-value $\left.=0.151\right)$ and geographical location $\left(\chi^{2}(2)=0.910 ; p\right.$-value $=$ $0.634)$. Some differences instead emerged considering the size measured as classes of employees $\left(\chi^{2}(3)=659.3848 ; p\right.$-value $\left.=0.000\right)$ : firms with 50 or fewer employees are under-represented while firms with at least 250 employees are over-represented. This reflects the difficulties in finding contact information for CEOs of the smaller firms. Nevertheless, the proportion of firms in the usable sample (241) and the contacted one $(3,899)$ is quite similar, suggesting that the sample is representative with respect to the number of employees.

The tests also revealed no particular issues with non-response bias, which we assessed by comparing respondents vs non-respondents, early vs late respondents (i.e. those who completed the questionnaire after three emails) and full vs dropped-out respondents (i.e. those who only partially answered the questionnaire). We compared respondents $(241)$ vs non-respondents $(3,658)$ along with the same dimensions above and found differences only for geographic location $\left(\chi^{2}(2)=8.061, p\right.$-value $\left.=0.018\right)$ while these respondents do not differ in terms of size $(t$-statistic $=-0.856, p$-value $=$ $0.392)$ and industry $\left(\chi^{2}(1)=0.004, p\right.$-value $\left.=0.952\right)$. Full (241) and dropped (114) respondents do not differ in both size $(t$-statistic $=-0.341, p$-value $=0.774)$, industry $\left(\chi^{2}(1)=0.028, p\right.$-value $\left.=0.868\right)$ and geographic location $\left(\chi^{2}(2)=2.498, p\right.$-value $=$ $0.287)$. In this case, given the available information, we compared CEOs also by gender $\left(\chi^{2}(1)=0.109, p\right.$-value $\left.=0.741\right)$ and age $(t$-statistic $=-1.559, p$-value $=$ 0.120 ), finding no difference. Finally, considering early (139) vs late (102) respondents, we did not find differences in terms of size ( $t$-statistic $=0.280, p$-value $=$ $0.774)$ and industry $\left(\chi^{2}(1)=0.004, p\right.$-value $\left.=0.948\right)$ while they differ in their geographic location $\left(\chi^{2}(2)=15.127, p\right.$-value $\left.=0.001\right)$, as CEOs closer to the university that administered the survey responded faster.

Finally, we checked the reliability of CEOs' answers by crosschecking them with secondary sources, when possible (i.e. for non-perceptive variables and constructs concerning the firm or CEO characteristics) and with answers gathered from a second questionnaire administered to the CEOs' Chief Human Resource Officers (CHROs). Specifically, 114 CEOs provided contact information of their $\mathrm{CHROs}$ and 43 of these replied to the questionnaire. According to their Average Deviation Index (Burke and Dunlap, 2002; Danneels, 2015), the matching of CEOs' and CHROs' answers revealed no significant differences. The interrater agreement was indeed acceptable for all items and constructs evaluated through Likert-like scales (i.e. lower than 0.80 in the case of five-point scales and 1.20 for seven-point scales; Burke and Dunlap, 2002). Moreover, the average deviation index (ADI) was always lower than 1, meaning that the responses of the CEOs and CHROs differed by an average of less than 1 scale point (Danneels, 2015). For the items that did not refer to constructs (30 items out of $43 ; 69.77 \%$ ), the ADI was lower than 0.05 , demonstrating an average difference lower than 0.50 scale points.

\section{About the authors}

Emanuela Rondi (PhD in Management; Lancaster University, 2016) is an Assistant Professor at the Department of Management at the Università degli Studi di Bergamo. Her research lies at the intersection of the family business and social capital, with a particular interest in the impact of relationships on intergenerational and innovation dynamics. Her research has been published on leading academic journals as the Journal of Management, Entrepreneurship Theory and Practice, Journal of Management Studies, Journal of World 
Business, Strategic Organization and Journal of Family Business Strategy. Emanuela Rondi is the corresponding author and can be contacted at: Emanuela.Rondi@unibg.it

Paola Rovelli (PhD in Management, Economics and Industrial Engineering; Politecnico di Milano, 2017) is an Assistant Professor at the Faculty of Economics and Management at the Free University of Bozen-Bolzano, working at the Center for Family Business Management. She carries out research on the organizational design of firms and their Top Management Teams, with particular attention toward family firms, the delegation of decision authority, narcissism and gender issues. Her research has been published on leading academic journals as European Management Journal, Journal of Management Studies, Long Range Planning, Personality and Individual Differences and The Leadership Quarterly.

For instructions on how to order reprints of this article, please visit our website: www.emeraldgrouppublishing.com/licensing/reprints.htm

Or contact us for further details: permissions@emeraldinsight.com 